\title{
PENGARUH KEJELASAN SASARAN ANGGARAN, SISTEM PENGENDALIAN INTERNAL, SDM DAN MOTIVASI TERHADAP KINERJA APARATUR DESA DI KEC. SINGINGI HILIR KAB. KUANTAN SINGINGI
}

\author{
Sonia Sischa Eka Putri \\ Universitas Islam Negeri Sultan Syarif Kasim Riau \\ Sonia.sischa@uin-suska.ac.id
}

\begin{abstract}
This study aims to examine: (1) the influence of budget clarity on the performance of village officials, (2) the influence of Internal Control on the performance of village officials, (3) the influence of Human Resources on the performance of village officials, (4) the influence of Motivation on the performance of village officials. The study was conducted at a village located in the district of Singingi Hilir, Kuantan Singingi. The Result showed that (1) budget clarity has significant influence on the performance of village officials, (2) Internal Control has significant influence on the performance of village officials, (3) Human Resources has significant influence on the performance of village officials, (4) Motivation has significant influence on the performance of village officials.
\end{abstract}

Keywords: The Performance of Village Officials, Budget Clarity, Internal control system, Human resources, Motivation.

\begin{abstract}
Abstrak
Penelitian ini bertujuan untuk mengetahui pengaruh: (1) Kejelasan Sasaran Anggaran terhadap kinerja aparatur desa, (2) Sistem Pengendalian Internal terhadap kinerja aparatur desa, (3) Sumber Daya Manusia terhadap kinerja aparatur desa dan (4) Motivasi terhadap Kinerja Aparatur Desa. Penelitian dilaksanakan di Desa yang terletak di Kecamatan Singingi Kabupaten Kuantan Singingi. Hasil penelitian menunjukkan bahwa: (1) Kejelasan Sasaran Anggaran berpengaruh terhadap kinerja aparatur desa, (2) Sistem Pengendalian Internal berpengaruh terhadap kinerja aparatur desa, (3) Sumber Daya Manusia berpengaruh terhadap kinerja aparatur desa dan (4) Motivasi berpengaruh terhadap Kinerja Aparatur Desa.
\end{abstract}

Kata Kunci: Kinerja Aparatur Desa, Kejelasan Sasaran Anggaran, Sistem Pengendalian Internal, Sumber Daya Manusia, Motivasi. 


\section{PENDAHULUAN}

Pembangunan nasional sedang gencar-gencarnya dilakukan pemerintah untuk menghadapi era globalisasi ini, pemerintah sebagai penggerak perkembangan pembangunan melakukan upaya pemerataan pembangunan disetiap sudut nusantara, salah satunya adalah pembangunan desa. Pembangunan desa merupakan salah satu fokus utama pemerintah saat ini untuk mencapai pembangunan nasional yang unggul dan merata. Diharapkan dengan melakukan pembangunan nasional yang merata kedepan dapat memperkuat, memberdayakan, dan mendorong desa sebagai pilar penting dalam mengatasi masalah kemiskinan, kesenjangan, dan ketertinggalan yang masih dapat ditemui diberbagai daerah di Indonesia. Dalam kaitan itu, misi pembangunan nasional dapat tercapai apabila pemerataan pembangunan baik di Propinsi, kota dan desa telah merata.

Program pengembangan desa yang telah digaungkan oleh pemerintah dapat dicapai dengan salah satu cara yaitu pemberian dana desa. Dimulai sejak tahun 2015 pemerintah telah menyalurkan dana desa sebagai salah satu kebijakan penganggaran Dana Desa yang bersumber dari Anggaran Pendapatan dan Belanja Negara (APBN). Dalam Peraturan Mentri Desa, Pembangunan Daerah Tertinggal dan Transmigrasi Republik Indonesia No. 21 Tahun 2015 Pasal 1 ayat 2 menjelaskan bahwa dana desa bersumber dari APBN yang kemudian ditransfer kepada desa melalui APBD Kabupaten/kota yang diperuntukkan untuk menyelenggarakan pemerintahaan, pelaksanaan pembangunan, pembinaan kemasyarakatan dan pemberdayaan masyarakat.

Pengalokasian dana desa ini bertujuan untuk meningkatkan pelayanan publik di desa, mengentaskan kemiskinan, memajukan perekonomian desa, mengatasi kesenjangan pembangunan antar desa, serta memperkuat masyarakat desa sebagai subjek dari pembangunan hal ini sesuai dengan UU No.6 Tahun 2014 Tentang Desa. Dengan tercapainya tujuan pemberian dana desa maka pembangunan yang digaungkan oleh pemerintah dapat tercapai dengan optimal. Hal ini akan memberikan dampak yang menguntungkan masyarakat sebagai prioritas utama pemerintah. 
Fenomena yang ditemui salah satunya adalah fakta yang terjadi di lapangan dan dialami oleh Anggota Komisi A DPRD Kabupaten Rembang yang menemukan sejumlah aparatur desa belum memberikan pelayanan maksimal kepada masyarakat. Ketua Komisi A DPRD Rembang, M Asnawi, saat menggelar pengawasan menemukan Kantor Desa Randuagung, Kecamatan Sumber, Kabupaten Rembang tertutup dan digembok pada saat jam kerja. Dari keterangan warga, didapatkan informasi bahwa kantor desa sudah beberapa bulan tidak dibuka. Padahal semestinya kantor desa itu harus buka setiap hari kerja untuk memberikan pelayanan bagi warga yang membutuhkan (Suaramerdeka.com).

Fenomena yang terjadi di daerah Kuantan Singingi dapat dilihat dari adanya keluhan masyarakat yang menyebutkan bahwa saat ini birokrasi dan pelayanan publik di Kabupaten Kuantan Singingi masih mengalami berbagai masalah, mulai dari tidak paham akan tupoksinya, tidak disiplin, serta meninda-nunda tugas kedinasan. Hal ini disampaikan bupati dalam rapat koordinasi pejabat Pemerintah Kabupaten Kuansing angkatan ke II di hotel ayola Pekanbaru (ranahriau.com).

Dari fenomena diatas dapat terlihat bahwa adanya pelayanan yang buruk terhadap masyarakat yang secara otomatis sudah menggambarkan buruknya kinerja yang dihasilkan oleh Kantor desa sebagai pelayan masyarakat.

Tabel 1. Indeks Pembangunan Desa Per 20 Juli 2019

\begin{tabular}{|l|l|l|l|}
\hline NO & \multicolumn{1}{|c|}{ STATUS } & \multicolumn{1}{|c|}{ JUMLAH } & \multicolumn{1}{|c|}{ PERSENTASE (\%) } \\
\hline 1 & Desa Tertinggal & 14.461 & $19,17 \%$ \\
\hline 2 & Desa Berkembang & 55.369 & $73,40 \%$ \\
\hline 3 & Desa Mandiri & 5.606 & $7,43 \%$ \\
\hline JUMLAH & $\mathbf{7 5 . 4 3 6}$ & \\
\hline
\end{tabular}

Sumber: Publikasi Badan Pusat Statistik

Selain fenomena diatas, kita juga dapat mengambil kesimpulan berdasarkan data tabel di atas, dapat dilihat dengan jelas bahwa desa dengan status mandiri masih rendah yaitu berkisar di angka 5.606 desa atau sekitar 7,43\%. Angka ini sangat rendah apabila dibandingkan dengan jumlah desa yang mencapai 75.436 desa. 
Dimana hal ini masih sangat jauh dari target sasaran pengembangan wilayah perdesaan dalam Rencana Pembangunan Jangka Menengah Nasional (RPJMN) 20152019 yaitu mengurangi jumlah desa tertinggal dan meningkatkan desa mandiri (Buku pintar Kemenkeu, 2016). RPJMN sendiri merupakan dokumen 5 tahunan dan merupakan pengejawantahan Visi dan Misi dari Presiden (Nawacita). Dari hasil tabel tersbut dapat dilihat bahwa aparatur desa sebagai pengelola pemerintahan desa dan penggerak kemajuan desa masih belum mampu mendorong peningkatan perkembangan desa sehingga sampai pada tahun 2018 masih terbilang sedikit desa yang masuk dalam kategori Mandiri.

Berdasarkan fenomena yang terjadi, maka penulis tertarik untuk meneliti kembali kinerja pada aparatur desa. Tujuan dari penelitian ini adalah untuk mengetahui apakah Kejelasan Sasaran Anggaran, Sistem Pengendalian Internal, Sumber Daya Manusia dan Motivasi mempengaruhi Kinerja Aparatur Desa.

\section{TELAAH LITERATUR DAN PENGEMBANGAN HIPOTESIS}

\section{KINERJA APARATUR DESA}

Dalam peraturan perundang-undangan pemerintahan Desa dan Kelurahan, pasal 1 ayat 7, tentang peraturan Pemerintah Desa menyatakan bahwa pemerintah Desa atau yang disebut dengan nama lain adalah kepala Desa dan perangkat Desa sebagai unsur penyelenggara pemerintahan Desa. Sedangakan pasal 1 ayat 6 menyatakan bahwa pemerintahan Desa adalah penyelenggaraan urusan pemerintahan oleh Pemerintah Desa dalam mengatur dan mengurus kepentingan masyarakat setempat berdasarkan asal-usul dan adat istiadat setempat yang diakui dan dihormati dalam sistem pemerintahan Negara Kesatuan Republik Indonesia.

Pembangunan masyarakat desa dapat dilaksanakan dibawah pimpinan Aparatur Pemerintah Desa. Aparatur Pemerintah Desa merupakan unsur yang harus ada dalam penyelenggaraan pemerintahan desa. Berdasarkan Undang-Undang No. 32 Tahun 2004 tentang Pemerintahan Daerah, menjelaskan bahwa Aparatur Pemerintah Desa adalah Kepala Desa dan Perangkat Desa. Aparatur Pemerintah Desa merupakan penyelenggara pemerintahan di desa yang memiliki tugas-tugas pokok. Salah satu 
tugas pokok Aparatur Pemerintah Desa adalah memberikan pelayanan umum atau publik kepada masyarakat. Sehingga dari pengertian ini kita dapat mengambil teori mengenai kinerja pegawai sebagai dasar penelitian ini.

Menurut Mangkunegara (2011:67) yang dimaksud dengan kinerja adalah hal yang telah dicapai oleh seorang pegawai. Kinerja merupakan hasil kerja yang dapat dicapai oleh seseorang atau kelompok orang dalam suatu perusahaan sesuai dengan wewenang dan tanggung jawab masing-masing dalam upaya pencapaian tujuan perusahaan yang dilakukan secara legal, tidak melanggar hukum dan tidak bertentangan dengan moral atau nilai etika. Dari pengertian tersebut dapat ditarik kesimpulan bahwa kinerja merupakan hasil kerja yang dicapai oleh pegawai baik secara individu maupun kelompok yang dapat dilihat dari kualitas dan kuantitas hasil kinerja yang berdampak langsung pada output/pencapaian tujuan organisasi melalui ketepatan pelaksanaan tugas sesuai dengan wwenang dan tanggung jawabnya.

Kinerja yang dihasilkan oleh pegawai dapat dibedakan menjadi dua, yaitu kinerja individu dan kinerja organisasi. Kinerja individu merupakan kinerja yang dihasilkan oleh pegawai secara mandiri baik dari segi kualitas maupun kuantitas sesuai dengan standar yang telah ditentukan. Sedangkan kinerja organisasi adalah hasil keseluruhan kinerja individu yang akan menghasilkan kinerja kelompok guna mencapai tujuan organisasi. Kinerja merupakan hasil atau output dari sebuah kegiatan yang dilakukan melalui berbagai proses dalam pencapaian organisasi. Penilaian kinerja dibutuhkan bagi pihak manajerial sebagai bentuk capaian strategi melalui alat ukur finansial maupun non finansial.

\subsection{Pengukuran Kinerja}

Pengukuran Kinerja pegawai yang digunakan berdasarkan Penilaian Kinerja Pegawai yang diatur dalam Peraturan Pemerintah Nomor 46 Tahun 2011 tentang Penilaian Prestasi Kerja Pegawai Negeri Sipil terdiri atas unsur sebagai berikut: Efektifitas dan efisiensi, Otoritas, Tanggung jawab, Disiplin, dan Inisiatif.

Dari pengertian diatas dapat dikatakan bahwa kinerja pegawai kepemerintahan dapat dilihat dan diukur dari efektifitas dan efisiensi pekerjaan, 
disiplin dalam bekerja, memiliki inisiatif terhadap pekerjaan serta bertanggung jawab atas tugas maupun pekerjaan yang dilimpahkan kepadanya.

Pengukuran kinerja pegawai ini juga merupakan salah satu alat ukur yang dapat digunakan untuk mengukur kinerja yang dihasilkan oleh aparatur desa, dimana aparatur desa sebagai pelayan publik harus bisa menunjukkan pncapaian atas tugas dan wewenang yang diberikan kepadanya, apakah proses administrasi yang dilakukan sudah efektif dan efisien, setiap tugas yang diberikan sudah dilaksanakan dengan tepat dan bertanggung jawab, serta memiliki tingkat kedisplinan dan inisiatif yang tinggi.

\section{Kejelasan Sasaran Anggaran}

Menurut Kenis (1979) dalam Bangun (2009), Kejelasan sasaran anggaran adalah sejauh mana tujuan anggaran ditetapkan secara jelas dan spesifik dengan tujuan anggaran dapat dimengerti oleh orang yang bertanggungjawab atas pencapaian sasaran anggaran tersebut. Apabila penggunaan anggaran dana desa sudah dipahami tujuan dan peruntukkannya maka setiap pegawai yang bertanggung jawab dan memiliki wewenang terhadap pengelolaan anggaran tersebut dapat dialokasikan tepat sasaran.

Kejelasaan sasaran anggaran merupakan salah satu factor yang dapat menunjang keberhasilan tercapainya tujuan organisasi, kejelasan terhadap pengalokasian anggaran yang diserap oleh setiap desa akan berdampak berbeda tergantung program kinerja dan output yang dihasilkan dari kinerja pegawai tersebut dalam mengelola anggaran desanya. Apabila setiap aparatur desa sudah memiliki pengetahuan dan wawasan yang jelas terhadap penggunaana nggaran maka output yang dihailkan akan tepat sasaran dan dapat memberikan dampak positif bagi masyarakat desa dan perkembangan desa itu sendiri.

\section{Sistem Pengendalian Internal}

Di dalam standar profesional akuntan publik (SPAP) pengendalian internal didefinisikan sebagai: "Pengendalian intern meliputi struktur organisasi, metoda dan ukuran-ukuran yang digunakan untuk mencapai tujuan, mengecek ketelitian serta 
keandalan data akuntansi, mendorong efisiensi, menjaga kekayaan organisasi, dan dipatuhinya kebijakan pimpinan".

Pengertian lainnya terkandung dalam PP No.60 Tahun 2008 tentang sistem pengendalian internal yang memiliki pengertian bahwa pengendalian internal merupakan proses yang integral pada tindakan dan kegiatan yang dilakukan secara terus menerus oleh pimpinan dan seluruh pegawai untuk memberikan keyakinan memadai atas tercapainya tujuan organisasi melalui kegiatan yang efektif dan efisien, keandalan pelaporan keuangan, pengamanan aset negara, dan ketaatan terhadap peraturan perundang-undangan.

Berdasarkan pengertian-pengertian di atas dapat ditarik kesimpulan bahwa yang dimaksud dengan pengendalian internal merupakan sebuah proses yang dilakukan secara terus menerus oleh setiap bagian entitas organisasi atau setiap individu yang berada dalam naungan organisasi yang terdiri dari serangkaian tindakan yang telah terintegrasi guna memberikan keyakinan yang memadai dan wajar untuk pencapaian tujuan organisasi.

\section{Sumber Daya Manusia}

Menurut Marwoto (2012) kualitas SDM adalah tingkat pengetahuan kemampuan dan kemauan yang dapat ditunjukan oleh sumber daya manusia. Tingkat tersebut dibandingkan dengan tingkat yang dibutuhkan dari waktu kewaktu oleh organisasi yang memiliki sumber daya manusia tersebut.

Sumber daya manusia yang berkualitas akan memberikan dampak positif bagi tercapainya tujuan organisasi, dengan sumber daya manusia yang mumpuni maka kinerja yang dihasilkanpun akan tepat dan sesuai. Sumber daya manusia yang memiliki kualitas dapat terlihat dari tingkat pendidikan, kesesuaian tugas latar belakang pendidikan, serta kecepatan dan ketepatan pelaksanaan tugas. Dalam perannya sumber daya manusia diibaratkan sebagai pondasi untuk mencapai tujuan sebuah organisasi, apabila pondasi tersebut sudah kokoh, maka bangunan tidak akan mudah tergoyahkan. Sumber daya manusia yang berkualitas merupakan alat ukur yang dapat dijadikan acuan tingkat keberhasilan sebuah organisasi, kinerja yang dihasilkan individu yang berkualitas akan menunjang percepatan tercapainya tujuan. 


\section{Motivasi}

Menurut John W Santrock (2010), motivasi adalah proses memberi semangat, arah, dan kegigihan perilaku. Artinya, perilaku yang termotivasi adalah perilaku yang penuh energi, terarah dan bertahan lama. Motivasi merupakan salah satu faktor penting yang dapat memberikan dukungan bagi setiap pegawai dalam melaksanakan tujuan organisasi. Dalam Kamus Besar Bahasa Indonesia (KBBI) dijelaskan pengertian dari motivasi yaitu :

a. dorongan yang timbul dari diri seseorang baik secara sadar atau tidak sadar untuk melakukan tindakan tertentu atau mencapai tujuan tertentu.

b. Usaha yang dapat menyebabkan seseorang atau sekelompok orang menjadi tergerak untuk melakukan sesuatu karena ingin mencapai suatu tujuan tertentu atau mendapatkan kepuasan dari hal yang ingin dilakukan tersebut

Dari definisi KBBI tersebut dapat dikatakan bahwa motivasi adalah dorongan dari dalam diri setiap individu untuk melakukan atau mencapai sesuatu tujuan tertentu untuk mendapatkan kepuasan, hal ini sesuai dengan faktor yang mempengaruhi kinerja yaitu motivasi, dimana motivasi yang dimiliki setiap pegawai berperan penting untuk mencapai tujuan dari sebuah organisasi.

\section{Pengaruh Kejelasan sasaran anggaran terhadap kinerja aparatur desa}

Sistem penganggaran memiliki karakteristik dimana salah satunya adalah kejelasan sasaran anggaran. Kejelasan sasaran anggaran adalah sejauh mana tujuan anggaran ditetapkan secara jelas, tepat sasaran, dan spesifik sesuai standar pada jangka waktu yang tepat dengan tujuan agar anggaran tersebut dapat dimengerti oleh anggota untuk dikoordinasi atas pencapaian sasaran kinerja yang ditetapkan (Putra, 2013).

Dengan adanya kejelasan sasaran anggaran, aparat pelaksana anggaran akan terbantu dalam perealisasiannya yang secara langsung juga mempengaruhi kinerja aparatnya. Namun jika ada ketidakjelasan sasaran anggaran akan menyebabkan pelaksana anggaran menjadi bingung, tidak tenang dan tidak puas dalam bekerja. Hal ini akan menyebabkan pelaksana anggaran tidak termotivasi untuk mencapai kinerja yang diharapkan (Syafrial, 2009). 
Setiap anggaran yang diserap oleh daerah dapat menjadi tolak ukur pencapaian kinerja yang diharapkan, sehingga perencanaan anggaran daerah bisa menggambarkan sasaran kinerja secara jelas. Setiap individu di sebuah organisasi selayaknya mengetahui dengan jelas anggaran yang diterima dan penggunaan anggaran tersebut. Pengelolaan anggaran yang baik dan pengawasan yang dilakukan pada setiap kegiatan yang dilakukan akan mempercepat pencapaian sasaran tujuan organisasi, baik organisai di pusat, daerah hingga ke desa.

Penelitian mengenai kinerja manajerial oleh Putra (2013). menemukan bahwa Kejelasan Sasaran Anggaran berpengaruh signifikan positif terhadap kinerja manajerial Satuan Kerja Perangkat Daerah (SKPD).

\section{$\mathrm{H}_{1}$ : Kejelasan Sasaran Anggaran berpengaruh terhadap kinerja aparatur desa.}

\section{Pengaruh Pengendalian Intern Terhadap Kinerja Aparatur Desa}

Pengendalian intern yang lemah di dalam sebuah organisasi pemerintah baik organisasi di Propinsi, Kota hingga Desa sangat berdampak terhadap pembangunan daerah tersebut. Lemahya pengendalian intern akan memberikan dampak pada tidak terdeteksinya kecurangan atau ketidaksesuaian proses akuntansi sehingga data yang diperoleh menjadi tidak kompoten. Apabila organisasi pemerintah telah melakukan proses pengendalian intern dengan benar pada satuan unitnya, maka tujuan organisasi akan tercapai. Pengendalian internal yang baik akan berdampak pada pencapaian tujuan, hasil dari data akuntansi, kinerja yang efisien, dapat menjaga kekayaan organisasi, serta dilaksanakannya kebijakan pimpinan.

Pengendalian intern sangat dibutuhkan dalam keberlangsungan tata pemerintahan, apabila pengendalian intern telah dilakukan dengan baik maka setiap komponen organisasi dapat dengan jelas melaksanakan tugasnya. Dampak dari pelaksanaan pengendalian intern yang dilakukan secara terus menerus akan memberikan rasa percaya terhadap pencapaian tujuan organisasi oleh setiap anggota organisasi tersebut.

Penelitian terdahulu mengenai pengaruh pengndalian intern terhadap kinerja pegawai dikemukakan oleh Amelia (2014) Febriandi (2013) menguji hubungan 
pengendalian intern dengan kinerja, hasil penelitian menunjukkan bahwa pengendalian intern berpengaruh terhadap kinerja pegawai.

\section{$\mathrm{H}_{2}$ :Sistem Pengendalian Intern berpengaruh terhadap kinerja aparatur desa.}

\section{Pengaruh Sumber Daya Manusia terhadap Kinerja Aparatur Desa}

Mangkunegara (2011:10) menyatakan bahwa Sumber Daya Manusia yang berkualitas dituntut untuk memiliki tingkat pengetahuan yang memadai atau paling tidak memiliki kemauan yang besar untuk terus belajar dan menambah pengetahuan. Untuk menilai kualitas dan kuantitas dari Sumber Daya Manusia dalam melaksanakan suatu fungsi untuk mecapai tujuannya, termasuk akuntansi dapat dilihat dari kompetensi sumber daya tersebut.

Kompetensi Sumber Daya Manusia dapat terlihat dari latar belakang pendidikan yang dimiliki oleh setiap pegawai, pelatihan-pelatihan yang pernah diikuti, pengalaman dalam bekerja ataupun keterampilan dalam menjalankan tugas. Kualitas Sumber Daya Manusia tidak hanya dapat diukur berdasarkan latar belakang yang dimiliki oleh individu, penilaiannya juga dapat dilihat dari kinerja yang telah dicapai untuk meningkatkan efektifitas di dalam pekerjaannya, dibutuhkan juga latihan yang di lakukan oleh pihak organisasi dalam memberikan wawasan yang lebih luas bagi pegawainya. Peningkatan kompetensi pegawai yang dilakukan oleh organisai dengan mengikutsertakan pegawai nya dalam pelatihan-pelatihan, pengintegrasian tugas sesuai keahlian dan factor penunjang lainnya. Apabila organisasi telah memebrikan berbagai pengalaman dan pengembangan terhadap sumber daya manusia yang dimilikinya, maka kinerja yang dihasilkan di kantor pemerintahan seperti desa akan terlaksana dengan efektif dan efisien.

Menurut penelitian yang dilakukan Marwoto (2013) menyatakan bahwa kualitas sumber daya manusia berpengaruh terhadap kinerja pegawai, hal ini di dukung dengan Hasil penelitian Arimbawa dan Dewi (2013).

\section{$\mathrm{H}_{3}$ : Sumber Daya Manusia berpengaruh terhadap kinerja aparatur desa.}




\section{Pengaruh Motivasi terhadap Kinerja Aparatur Desa}

Robbins and Judge (2007) menyatakan bahwa motivasi merupakan proses yang menjelaskan intensitas, arah dan ketekunan seorang individu untuk mencapai tujuan. Motivasi memiliki hubungan langsung dengan kinerja yang akan dihasilkan oleh setiap individual karyawan, apabila karyawan memiliki motivasi yang tinggi, maka karyawan tersebut akan memiliki tingkat produktivitas yang tinggi, serta laju hasil kinerja terhadap tujuan organisasi juga akan berjalan baik, sehingga menghasilkan kinerja dan pencapaian yang maksimal bagi pemerintah. Para pegawai di organisasi pemerintah daerah memiliki motivasi di dalam melakukan pengembangan diri dan tingkat sosialisasi. Motivasi yang tinggi biasanya di dorong oleh tingkat kebutuhan yang dimiliki, dimana tingkat kebutuhan ini berbeda-beda pada setiap individu, ada yang memiliki motivasi untuk mencapai tujuan pengembangan diri, materi, ataupun pengakuan pihak lain.

Menurut penelitian yang dilakukan Shadare dan Hammed (2009) di Nigeria terhadap pegawai pemerintah, Kumar dan Garg (2010) yang meneliti di India terhadap kinerja pegawai pemerintah daerah setempat menyatakan bahwa faktor motivasi memiliki pengaruh terhadap kinerja pegawai.

\section{H4: Motivasi berpengaruh terhadap kinerja aparatur desa.}

\section{METODE PENELITIAN}

Populasi penelitian ini adalah kepala desa/ sekretaris desa/ bendahara desa/ kepala urusan pemerintahan desa dan kepala seksi pemerintahan desa. Teknik pengambilan sampel dalam penelitian ini menggunakan teknik purposive sampling. Purposive sampling diambil dengan tujuan untuk menyesuaikan kriteria dengan objek penelitian. Metode yang digunakan untuk pengumpulan data adalah data primer yaitu kuesioner yang disampaikan secara langsung. Jumlah kuesioner yang disebarkan adalah 63 eksemplar. 


\section{HASIL DAN PEMBAHASAN}

\section{Data Demografi Responden}

Kuisioner di sebarkan kepada seluruh kepala desa/ sekretaris desa/ bendahara desa/ kepala urusan pemerintahan desa dan kepala seksi pemerintahan desa. Jumlah kuesioner yang disebarkan sebanyak 63 kuesioner yang diserahkan secara langsung. Dari 63 kuesioner yang disebarkan hanya 57 kuesioner yang kembali atau sebanyak $91 \%$.

Tabel 2 Hasil Uji Reliabilitas Data

\begin{tabular}{|l|l|l|}
\hline Variabel & Standar & Cronbach's Alpha \\
\hline Kinerja Aparatur desa & 0,60 & 0.909 \\
\hline Kejelasan Sasaran Anggaran & 0,60 & 0.884 \\
\hline Pengendalian Intern & 0,60 & 0.686 \\
\hline Sumber Daya Manusia & 0,60 & 0.949 \\
\hline Motivasi & 0,60 & 0.903 \\
\hline
\end{tabular}

Sumber: data olahan, 2019

Berdasarkan hasil pengujian reliabilitas data untuk seluruh variabel independen, diperoleh hasil Cronbatch Alpha lebih besar dari 0.6 yang berarti bahwa data tersebut reliabel.

\section{Tabel 4 Hasil Analisis Regresi Berganda}

\begin{tabular}{|l|l|l|l|}
\hline \multirow{2}{*}{ Model } & \multicolumn{2}{|l|}{ Unstandardized Coefficients } & Standardized Coefficients \\
\cline { 2 - 4 } & B & Std. Error & Beta \\
\hline (Constant) & 16.302 & 5.763 & \\
\hline & .156 & .042 & .261 \\
\hline & .248 & .071 & .246 \\
\hline & .204 & .086 & .181 \\
\hline & .213 & .093 & .158 \\
\hline
\end{tabular}

Sumber: Data Olahan, 2019

Dari tabel 4 dapat diketahui bahwa persamaan regresi linear berganda dalam penelitian ini adalah sebagai berikut:

$$
\begin{aligned}
& \mathrm{Y}=\mathrm{a}+\mathrm{b} 1 \mathrm{X} 1+\mathrm{b} 2 \mathrm{X} 2+\mathrm{b} 3 \mathrm{X} 3+\mathrm{b} 4 \mathrm{X} 4+\mathrm{e} \\
& \mathrm{Y}=16,302+0,156 \mathrm{X} 1+0,248 \mathrm{X} 2+0,204 \mathrm{X} 3+0,213 \mathrm{X} 4+\mathrm{e}=\text { error. }
\end{aligned}
$$

Adapun maksud dari angka-angka yang terdapat dalam persamaan regresi linear berganda adalah: 
$\mathrm{a}=$ Nilai konstanta (a) sebesar 16,302. Artinya adalah apabila variabel independen diasumsikan nil (0), maka kinerja aparatur desa bernilai 16,302.

$\mathrm{b}_{1}=$ Nilai koefisien regresi variabel pengendalian intern $\left(\mathrm{X}_{1}\right)$ sebesar 0,156 Artinya adalah bahwa setiap peningkatan variabel kejelasan sasaran anggaran $\left(\mathrm{X}_{1}\right)$ sebesar 1 satuan maka akan meningkatkan variable kinerja aparatur desa (Y) sebesar 0,156 dengan asumsi variabel lainnya konstan.

$b_{2}=$ Nilai koefisien regresi variabel system pengendalian intern $\left(X_{2}\right)$ sebesar 0,248 Artinya adalah bahwa setiap peningkatan variable sistem pengendalian intern $\left(\mathrm{X}_{2}\right)$ sebesar 1 satuan maka akan meningkatkan variabel kinerja aparatur desa $(\mathrm{Y})$ sebesar 0,248 dengan asumsi variabel lainnya konstan.

$b_{3}=$ Nilai koefisien regresi variabel sumber daya manusia $\left(X_{3}\right)$ sebesar 0,204 Artinya adalah bahwa setiap peningkatan variabel sumber daya manusia $\left(\mathrm{X}_{3}\right)$ sebesar 1 satuan maka akan meningkatkan variabel kinerja aparatur desa (Y) sebesar 0,204 dengan asumsi variabel lainnya konstan.

$\mathrm{b}_{4}=$ Nilai koefisien regresi variabel kualitas motivasi $\left(\mathrm{X}_{4}\right)$ sebesar 0,213 Artinya adalah bahwa setiap peningkatan variabel motivasi $\left(\mathrm{X}_{4}\right)$ sebesar 1 satuan maka akan meningkatkan variabel kinerja aparatur desa (Y) sebesar 0,213 dengan asumsi variabel lainnya konstan.

\section{Hasil Uji Koefisien Determinasi}

Koefisien determinasi digunakan untuk menguji goodness of-fit dari model regresi, yaitu seberapa besar pengaruh variabel bebas (independen) terhadap variabel terikat (dependen).

Model Summary ${ }^{\mathrm{b}}$

\begin{tabular}{|l|l|l|l|l|}
\hline Model & R & R Square & Adjusted R Square & Std. Error of the Estimate \\
\hline 1 & $.818^{\mathrm{a}}$ & .670 & .644 & 2.526 \\
\hline
\end{tabular}

a. Predictors: (Constant), Kejelasan_sasaran_anggaran, Pengendalian_Intern, Sumber_daya_manusia, motivasi. Dependent Variable: Kinerja_aparatur-desa

Dependent Variable: Kinerja_aparatur_desa 


\section{Uji Signifikansi Parsial ( Uji t)}

\section{Coefficients $^{\mathrm{a}}$}

\begin{tabular}{|c|c|c|c|c|c|c|}
\hline \multirow{2}{*}{\multicolumn{2}{|c|}{ Model }} & \multicolumn{2}{|c|}{$\begin{array}{l}\text { Unstandardized } \\
\text { Coefficients }\end{array}$} & \multirow{2}{*}{$\begin{array}{l}\text { Standardized } \\
\text { Coefficients } \\
\text { Beta }\end{array}$} & \multirow[t]{2}{*}{$\mathrm{T}$} & \multirow[t]{2}{*}{ Sig. } \\
\hline & & B & Std. Error & & & \\
\hline \multirow{5}{*}{1} & (Constant) & -7.605 & 4.490 & & -1.694 & .096 \\
\hline & $\begin{array}{l}\text { Kejelasan_sasaran_ } \\
\text { anggaran }\end{array}$ & .300 & .101 & 260 & 2.968 & .005 \\
\hline & Pengendalian_Intern & .398 & .064 & .560 & 6.216 & .000 \\
\hline & SDM & .486 & .164 & .253 & 2.967 & .005 \\
\hline & Motivasi & .106 & .052 & .167 & 2.046 & .046 \\
\hline
\end{tabular}

a. Dependent Variable: Kinerja_aparatur_desa

Uji t digunakan untuk mengetahui seberapa jauh pengaruh satu variabel bebas/independen secara individual dalam menerangkan variabel terikat/dependen. Pengujian ini dapat dilakukan dengan membandingkan nilai t hitung dengan nilai $\mathrm{t}$ tabel. Apabila nilai $t_{\text {hitung }}>t_{t a b e l}$, maka Ho ditolak dan Ha diterima. Dalam penelitian ini diketahui bahwa nilai $t_{\text {tabel }}$ dengan $\mathrm{df}=52$, pada tingkat signifikan $\alpha / 2$ adalah sebesar 2.007. Hasil uji t dapat dilihat dalam tabel berikut:

Berdasarkan hasil uji statistik t pada tabel diatas, maka dapat disimpulkan sebagai berikut :

1. Uji Parsial untuk variabel kejelasan sasaran anggaran dari tabel 4, dapat dilihat bahwa hasil dari nilai t hitung kejelasan sasaran anggaran sebesar 2.968, dimana hasil ini lebih besar dari nilai t tabel sebesar 2.007, yang artinya bahwa terdapat pengaruh yang signifikan antara kejelasan sasaran anggaran terhadap kinerja aparatur desa di Kecamatan Singingi Hilir Kabupaten Kuantan Singingi. Hal ini ditunjukkan dengan tingkat signifikan sebesar 0,005 lebih kecil dari 0,05.

2. Uji Parsial untuk variabel pengendalian intern dari tabel 4.13, dapat dilihat bahwa hasil dari nilai t hitung untuk variabel Pengendalian Intern sebesar 6.216, dimana hasil ini lebih besar dari nilai t tabel sebesar 2.007, yang artinya bahwa terdapat pengaruh yang signifikan antara Pengendalian Intern kinerja aparatur desa di Kecamatan Singingi Hilir Kabupaten Kuantan Singingi. Hal ini juga ditunjukkan dengan tingkat signifikan sebesar 0,000 lebih kecil dari 0,05. 
3. Uji Parsial untuk variabel SDM dapat dilihat bahwa hasil dari nilai t hitung untuk variable SDM sebesar 2.967, dimana hasil ini lebih besar dari nilai t tabel sebesar 2.007, yang artinya bahwa terdapat pengaruh yang signifikan antara SDM terhadap kinerja aparatur desa di Kecamatan Singingi Hilir Kabupaten Kuantan Singingi. Hal ini ditunjukkan dengan tingkat signifikan sebesar 0,005 lebih kecil dari 0,05.

4. Uji Parsial untuk variabel motivasi dapat dilihat bahwa hasil dari nilai t hitung untuk variabel motivasi sebesar 2.046, dimana hasil ini lebih besar dari nilai t tabel sebesar 2.007, yang artinya bahwa terdapat pengaruh yang signifikan antara motivasi terhadap kinerja aparatur desa di Kecamatan Singingi Hilir Kabupaten Kuantan Singingi. Hal ini ditunjukkan dengan tingkat signifikan sebesar 0,046 lebih kecil dari 0,05.

Dari hasil tersebut dapat dilihat bahwa dengan adanya kejelasan sasaran anggaran, dapat membantu aparat pelaksana anggaran dalam hal ini aparatur desa untuk merealisasikan program desa yang secara langsung juga mempengaruhi kinerja aparat. Selain itu, pengendalian intern juga berpengaruh terhadap kinerja aparatur desa, dimana peran pengendalian intern sangat dibutuhkan dalam keberlangsungan tata pemerintahan, apabila pengendalian intern telah dilakukan dengan baik maka setiap komponen organisasi dapat dengan jelas melaksanakan tugasnya dan memberikan dampak positif bagi kinerja yang dihasilkan. Sumber Daya Manusia juga memiliki pengaruh terhadap kinerja aparatur desa, dimana kinerja yang dihasilkan oleh setiap individu yang berkualitas dapat berdampak terhadap kinerja yang dihasilkan, lebih efektif dan efisien. Yang terakhir adalah variable motivasi, dimana motivasi memiliki pengaruh terhadap kinerja yang akan dihasilkan oleh aparatur desa, apabila aparatur desa memiliki motivasi yang tinggi maka tingkat produktivitas aparatur desapun meningkat, serta laju hasil kinerja terhadap tujuan organisasi juga akan berjalan baik, sehingga menghasilkan kinerja dan pencapaian yang maksimal bagi pemerintah.

\section{SIMPULAN}

1. Kejelasan sasaran anggaran berpengaruh terhadap kinerja aparatur desa di Kecamatan Singingi Hilir Kabupaten Kuantan Singingi. Dengan pemahaman 
yang dimiliki oleh setiap pegawai atau aparatur desa tentang pentingnya kejelasan sasaran anggaran, maka aparatur desa dapat memahami secara jelas dan spesifik tujuan anggaran tersebut. Apabila penggunaan anggaran dana desa sudah dipahami tujuan dan peruntukkannya maka setiap pegawai yang bertanggung jawab akan memiliki wewenang terhadap pengelolaan anggaran tersebut shingga dapat dialokasikan tepat sasaran.

2. Pengendalian intern yang digunakan oleh setiap instansi dan diimplementasikan oleh setiap pegawai dalam melaksanakan tugasnya dapat meningkatkan kinerja pemerintah desa dan kinerja individual pegawai sebagai aparatur desa di Kecamatan Singingi Hilir, Kabupaten Kuantan Singingi.

3. Sumber Daya Manusia berpengaruh terhadap kinerja aparatur desa di Kecamatan Singingi Hilir, Kabupaten Kuantan Singingi. Dimana Semakin tinggi tingkat kualitas SDM dari para aparatur desa yang dimiliki oleh setiap kantor desa, dapat meningkatkan kinerja aparatur desa di Kecamatan Singingi Hilir, Kabupaten Kuantan Singingi.

4. Motivasi berpengaruh terhadap kinerja aparatur desa di Kecamatan Singingi Hilir, Kabupaten Kuantan Singingi. Kinerja yang akan dihasilkan oleh aparatur desa akan semakin baik apabila aparatur desa memiliki motivasi bekerja yang tinggi, semakin tinggi tingkat motivasi seorang pegawai dalam melaksanakan tugasnya akan berimbal balik terhadap pestasi kerja yang dihasilkan, sehingga kinerja aparatur desa di Kecamatan Singingi Hilir, Kabupaten Kuantan Singingi akan baik.

\section{DAFTAR PUSTAKA}

Arimbawa, dan Dewi. 2013. Pengaruh Budaya Organisasi, Gaya Kepemimpinan Dan, Motivasi Kerja Terhadap Kinerja Karyawan Pada Hotel Jimbaran Puri Bali. Jurnal Ekonomi Universitas Udayana, hal. 1693-1710.

Bangun, A. 2009. Pengaruh Partisipasi Dalam Penyusunan Anggaran, Kejelasan Sasaran Anggaran dan Struktur Desentralisasi Terhadap Kinerja Manajerial SKPD Dengan Pengawasan Internal Sebagai Variabel Pemoderasi (Studi 
Kasus Pada Pemerintah Kabupaten Deli Serdang). Medan: Program Pascasarjana Universitas Sumatera Utara.

Fahdi, M. 2015. Faktor-Faktor Yang Mempengaruhi Kinerja Badan Layanan Umum Di Universitas Riau (Tesis). Pekanbaru: Universitas Riau.

IAI (Ikatan Akuntansi Indonesia). 2011. Standar Profesional Akuntan Publik (SPAP). Jakarta: Salemba Empat.

Kumar, dan Garg, 2010. Impact of motivational factors on employee's job satisfaction- A study on some selected organization in Punjab, India. Asian Journal Of Management Research. Vol.2 No, 1. Hal. 672-683

Mangkunegara, Anwar Prabu. 2011. Manajemen Sumber Daya Manusia. Bandung: PT Remaja Rodakarya.

Pridarsanti, dan Yuyetta, 2013. Analisis faktor-faktor yang mempengaruhi kinerja pegawai (studi empiris pada pegawai direktorat jenderal perbendaharaan kementerian keuangan di kota semarang). Diponegoro Journal of Accounting, Vol. 2, No.3, hal. 1-14.

Peraturan Menteri Desa, Pembangunan Daerah Tertinggal, dan Transmigrasi Republik Indonesia Nomor 21 Tahun 2015 tentang Penetapan Prioritas Penggunaan Dana Desa Tahun 2016.

Peraturan Pemerintah Republik Indonesia Nomor 60 Tahun 2008. Sistem Pengendalian Intern Pemerintah.

Peraturan Pemerintah Nomor 46 Tahun 2011. Republik Indonesia tentang Penilaian Prestasi Kerja Pegawai Negeri Sipil.

Ranahriau.com

Robbins SP, dan Judge. 2007. Perilaku Organisasi, Salemba Empat, Jakarta.

Sawyer, Lawrence B., Mortimer A. Dittenhofer, dan James H. Scheiner. (2006). Internal Auditing. Buku 3: Jakarta Salemba Empat.

Suaramerdeka.com.

Undang-Undang Nomor 6 Tahun 2014 Tentang Desa, Lembaran Negara.

Undang-Undang Republik Indonesia Nomor 32 Tahun 2004 Tentang Pemerintahan Daerah. 